\title{
ASSOCIATION BETWEEN BODY MASS INDEX, TYPE OF OCCUPATION, HISTORY OF CHRONIC ILLNESS, AND POOR OCCUPATIONAL POSTURE
}

\author{
Dea Linia Romadhoni'), Setyo Sri Rahardjo²), Dono Indarto²) \\ ${ }^{1)}$ Masters Program in Public Health, Universitas Sebelas Maret \\ 2)Faculty of Medicine, Universitas Sebelas Maret
}

\begin{abstract}
Background: Good posture is important for an individual health as well as appearance. Poor occupational posture may cause negative impacts such as soreness \& pain, poor circulation, negative mood, increased stress, carpal tunnel syndrome, less motivation, poor digestion, and fatigue. The purpose of this study was to determine the association between body mass index, type of occupation, history of chronic illness, and poor occupational posture.

Subjects and Method: This was a cross-sectional study conducted at Dr. Moewardi hospital, Surakarta, Central Java, from April to May 2018. A sample of 116 patients was selected for this study by fixed disease sampling. The dependent variable was occupational posture. The independent variables were body mass index, type of occupation, and history of chronic illness. Occupational posture data were measured by Rapid Entry Body Assessment (REBA) questionnaire. The other variables were measured by questionnaire. The data were analyzed by a multiple logistic regression.

Results: Poor occupational posture was associated with body mass index $\geq 25$ $(\mathrm{OR}=0.99 ; 95 \% \mathrm{CI}=0.02$ to $1.96 ; \mathrm{p}=0.044)$, heavy occupational type $(\mathrm{OR}=2.24$; $95 \% \mathrm{CI}=1.34$ to $3.14 ; \mathrm{p}<0.001)$, and history of chronic illness $(\mathrm{OR}=0.78 ; 95 \% \mathrm{CI}=$ -0.10 to $1.67 ; \mathrm{p}=0.084$ ).

Conclusion: Poor occupational posture is associated with body mass index $\geq 25$, heavy occupational type, and history of chronic illness.
\end{abstract}

Keywords: occupational posture, body mass index, occupational type, history of illness

\section{Correspondence:}

Dea Linia Romadhoni. Masters Program in Public Health, Universitas Sebelas Maret, Jl. Ir. Sutami 36A, Surakarta, Central Java.

Email: dealiniao8@gmail.com. Mobile: 082227862718 